\title{
Thiosulphate as Electron Donor in the Blue-green Alga Anacystis nidulans
}

\author{
By H. C. UTKILEN \\ Botanical Laboratory, University of Oslo, Box I045, \\ Blindern, Oslo 3, Norway \\ (Received 6 November 1975; revised 23 January 1976) \\ INTRODUCTION
}

Blue-green algae are frequently observed in anaerobic environments (Brock, I973; Castenholtz, 1973), and there have been several reports of stimulation of growth in the laboratory under reducing conditions (Setlike, I957; Allen, I959; Ferguson Wood, 1965; Knoblock, I966; Stewart \& Pearson, 1970). Such results pose the question of whether an oxidizable inorganic substrate can act as an electron donor in photosynthesis, or whether such compounds merely create a reducing environment. It is known from laboratory studies that blue-green algae do not thrive under high oxygen tension (Sirenko et al., I968; Stewart, 1969; Stewart \& Pearson, 1970). Stewart \& Pearson (1970) suggested that the stimulating effect of hydrogen sulphide on growth of Anabaena flos-aquae was due to the removal of oxygen, but they also considered the possibility that hydrogen sulphide could act as an electron donor. Recently a blue-green alga has been isolated that can adopt either bacterialike photosynthetic growth at the expense of hydrogen sulphide, or the usual oxygen-evolving photosynthesis, depending on environmental conditions (Cohen et al., 1975).

This paper describes the effect of thiosulphate on the growth of Anacystis nidulans under light-limiting conditions. Thiosulphate is a potential electron donor that does not directly affect the oxygen tension.

\section{METHODS}

Organism. Axenic cultures of Anacystis nidulans I40I I (Algal Culture Collection, Institute of Plant Physiology, University of Göttingen, West Germany), purified by singlecolony isolation, were used, except in growth experiments where non-axenic cultures were used. In these initial experiments, some bacteria were present in the cultures, but in view of the small numbers observed ( $0.1 \%$ of the total number of cells), it was considered that their presence did not invalidate the results.

Growth conditions. Cultures were grown in glass cylinders $(4 \mathrm{~cm}$ diam.), with conical bottoms, containing $250 \mathrm{ml}$ medium, and incubated in a water bath at $42{ }^{\circ} \mathrm{C}$. Continuous illumination was provided by three Warm de Luxe Philips TL4O W/32 and two Daylight TL40 WI/55 fluorescent tubes. The medium was that described by Lorenzen \& Venkarataraman (I969), except that, where indicated, I mM- $\mathrm{MgSO}_{4}$ was replaced by I mM- $\mathrm{Na}_{2} \mathrm{~S}_{2} \mathrm{O}_{3}$ and $\mathrm{I} \mathrm{mM}-\mathrm{MgCl}_{2}$. Phosphate was autoclaved separately to avoid precipitation. Cultures were gassed and agitated with a mixture of air $/ \mathrm{CO}_{2}(98 \cdot 5: \mathrm{I} \cdot 5, \mathrm{v} / \mathrm{v})$. The light intensity was varied by changing the distance between the water bath and the light source. Unless otherwise stated, the algae were grown in a medium for about $24 \mathrm{~h}$, and were transferred to a similar medium at the start of each experiment.

Growth measurements. Numbers of cells were determined in a suitable dilution of the 

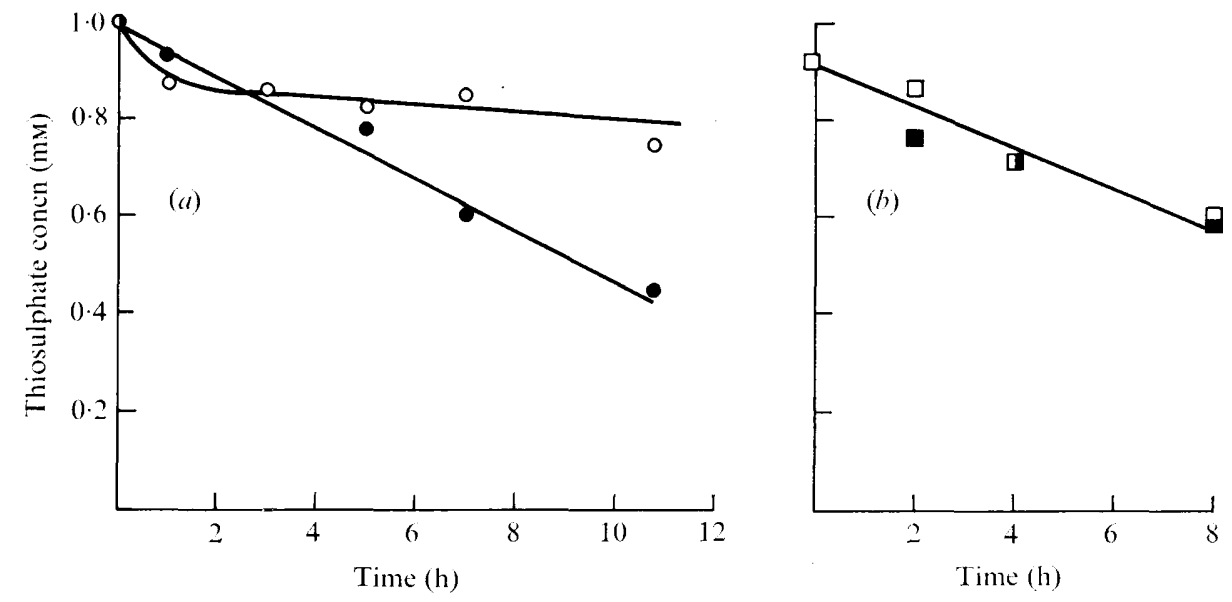

Fig. I. The effect of DBMIB and DCMU on oxidation of thiosulphate by $A$. nidulans. (a) O, I0 $\mu$ M-DBMIB; 0 , no inhibitor. (b) $\square$, Io $\mu \mathrm{M}-\mathrm{DCMU}$; $\mathbf{\square}$, no inhibitor.

culture using a Celloscope model 302 (Lars Ljungberg, Stockholm, Sweden), tube aperture $30 \mu \mathrm{m}$.

Estimation of light intensity. The photocell (Luxmeter 370-393, Joffe, Italy) was submerged in the water bath beside the culture vessel, thereby allowing determination of the incident light intensity at the surface of the vessel.

Estimation of $\mathrm{CO}_{2}$ uptake. $\mathrm{CO}_{2}$ fixation was measured in volumetric respirometers (Scholander \& Iversen, 1958) using 20 to $25 \mathrm{ml}$ flasks, under the same conditions as for growth, except that a row of five $25 \mathrm{~W}$ incandescent lamps was used for the experiments at I klx. The gas phase was air. Algae were grown in thiosulphate medium, harvested during exponential growth, washed twice with $\mathrm{I}$ mM- $\mathrm{MgCl}_{2}$ and resuspended in $\mathrm{I} \mathrm{mM}-\mathrm{MgCl}_{2}$. Portions ( $\mathrm{I} \mathrm{ml}$ ) of washed cell suspension were transferred to respirometer flasks containing I ml thiosulphate or sulphate medium and $15 \mu \mathrm{mol} \mathrm{NaHCO} . \mathrm{CO}_{2}$ uptake was stopped by adding $0.05 \mathrm{ml} 50 \%(\mathrm{w} / \mathrm{v})$ citric acid through the rubber injection stopper. The acid served both to inactivate the cells and to liberate from the medium the remaining bound $\mathrm{CO}_{2}$ which could then be measured. In each experiment one respirometer was used to measure the initial amount of bound $\mathrm{CO}_{2}$, and fixation was then calculated.

Estimation of thiosulphate oxidation. Thiosulphate was determined iodometrically, and sulphate turbidimetrically by precipitation with $\mathrm{BaCl}_{2}$ (Gleen \& Quastel, I953).

Inhibitors. 2,5-Dibromo-3-methyl-6-isopropyl-p-benzoquinone (DBMIB) was a gift from Professor W. A. Trebst. 3-(3,4-Dichlorophenyl)-I, I-dimethylurea (DCMU) was obtained from Kebo Grave Labsenter, Spånga, Sweden, and recrystallized from ethanol.

\section{RESULTS AND DISCUSSION}

With the experimental conditions used, optimal light intensity for growth of $A$. nidulans was about I4 klx (Utkilen, 1973). Growth of $A$. nidulans at this and suboptimal $(8.8 \mathrm{klx})$ light intensity showed that lowering the light intensity had no effect on the doubling time in cultures with thiosulphate, whereas the doubling time increased from $2 \cdot \mathrm{I}$ to $2 \cdot 8 \mathrm{~h}$ in cultures with sulphate.

Increasing the sulphate or thiosulphate concentration from I to $100 \mu \mathrm{M}$ caused the final 
cell yield to increase from $2.3 \times 10^{8}$ to $6.9 \times 10^{8}$ cells ml ${ }^{-1}$ in cultures containing sulphate and from $3.8 \times 10^{8}$ to $\mathrm{I} \cdot 0 \times \mathrm{IO}^{9} \mathrm{cells} \mathrm{ml}^{-1}$ in those containing thiosulphate, at optimal light intensities. While further increase in sulphate concentration had no effect, raising the concentration of thiosulphate to I $\mathrm{mm}$ resulted in a still higher cell yield $\left(\mathrm{I} \cdot 8 \times 10^{9} \mathrm{cells}^{-1}\right)$. The cell density at the start of the experiments was about $10^{6} \mathrm{cells}^{-1}$.

These results show that in light-limited conditions, $A$. nidulans can grow faster in the presence of an oxidizable inorganic substrate (thiosulphate) than in its absence. They also indicate that the algae can maintain growth in the presence of thiosulphate at light intensities that would not permit growth in its absence, since the lack of an increase in cell yield when sulphate concentrations were raised above $100 \mu \mathrm{M}$ must be due to light limitation.

The rate of $\mathrm{CO}_{2}$ fixation at different light intensities (o to $20 \mathrm{klx}$ ) was examined. A different algal suspension was used for experiments at each light intensity and the number of cells was not determined. There was no $\mathrm{CO}_{2}$ fixation with sulphate or thiosulphate in the dark. At I klx, the algae incubated with thiosulphate fixed $0.27 \mu \mathrm{mol} \mathrm{CO}_{2} \mathrm{ml}^{-1} \mathrm{~h}^{-1}$ whereas there was no $\mathrm{CO}_{2}$ fixation in the algae incubated with sulphate. At $8 \mathrm{klx}$ the algae incubated with thiosulphate fixed $0.85 \mu \mathrm{mol} \mathrm{CO}_{2} \mathrm{ml}^{-1} \mathrm{~h}^{-1}$ and the algae incubated with sulphate $0.45 \mu \mathrm{mol} \mathrm{CO}_{2} \mathrm{ml}^{-1} \mathrm{~h}^{-1}$. At $20 \mathrm{klx}$ the algae fixed $0.70 \mu \mathrm{mol} \mathrm{CO}_{2} \mathrm{ml}^{-1} \mathrm{~h}^{-1}$ in both cases. These results are in accord with those of the growth experiments.

The oxidation of thiosulphate appeared to be dependent on enzyme induction, as shown by the following experiment. Two cultures were grown at $8 \mathrm{klx}$, one with thiosulphate and the other with sulphate. Both were harvested during exponential growth and resuspended in thiosulphate medium to a density of about ${ }^{\circ} 0^{8}$ cells $\mathrm{ml}^{-1}$. The disappearance of thiosulphate and appearance of sulphate were followed. The thiosulphate-grown cells oxidized thiosulphate rapidly after a lag period of about $30 \mathrm{~min}$. The sulphate-grown cells required $2 \mathrm{~h}$ contact with thiosulphate before oxidation began, and then this was at a much slower, though increasing rate.

It is also evident that thiosulphate was completely oxidized to sulphate since $\mathrm{I} \cdot 0 \mu \mathrm{mol}$ thiosulphate gave about $2 \mu \mathrm{mol}$ sulphate (for which thiosulphate was the sulphur source); whereas Cohen et al. (1975) found that Oscillatoria limnetica oxidized hydrogen sulphide only as far as elemental sulphur.

To show that oxidation of thiosulphate was directly associated with photosynthesis, the effect of two inhibitors was examined. Cells growing in thiosulphate medium at $8 \mathrm{klx}$ were harvested during exponential growth and resuspended in the same medium to a density of about $10^{8}$ cells $\mathrm{ml}^{-1}$. DCMU, which is known to block photosystem II in blue-green algae (Krogmann, 1973), had no effect on thiosulphate oxidation by $A$. nidulans at a concentration of Io $\mu \mathrm{M}$, for at least $8 \mathrm{~h}$ (Fig. Ib). DBMIB has been reported (Trebst \& Harth, 1970) to inhibit electron transport between photosystems I and II close to, or at, the functional site of plastoquinone. When this halogenated quinone was added (Iо $\mu \mathrm{M})$, it inhibited the oxidation of thiosulphate by about $70 \%$ (Fig. $\mathrm{I} a$ ). The effect of thiosulphate on oxygen evolution has not been determined. It would appear that $A$. nidulans can utilize thiosulphate as an electron donor, in a manner analogous to that in bacterial photosynthesis, when the supply of ATP or of electrons from water is curtailed by light limitation.

Thanks are due to Dr J. G. Ormerod for valuable discussions. 


\section{REFERENCES}

Allen, M. B. (1959). Studies with Cyanidium caldarium, an anomalously pigmented chlorophyte. Archiv für Mikrobiologie 32, 270-277.

Brock, T. D. (1973). Evolutionary and ecological aspects of the cyanophytes. In The Biology of Blue-green Algae, pp. 489-500. Edited by N. G. Carr and B. A. Whitton. Oxford: Blackwell.

Castenholtz, R. W. (1973). Ecology of blue-green algae in hot springs. In The Biology of Blue-green Algae, pp. 379-4I4. Edited by N. G. Carr and B. A. Whitton. Oxford: Blackwell.

Cohen, Y., Jørgensen, B. B., Padan, E. \& Shilo, M. (I975). Sulphide-dependent anoxygenic photosynthesis in the cyanobacterium Oscillatoria limnetica. Nature, London 257, 489-492.

Ferguson Wood, E. J. (1965). Marine Microbial Ecology, pp. 47-48. London: Chapman and Hall.

Gleen, H., \& QuASTEL, J. H. (I953). Sulphur metabolism in soil. Applied Microbiology 1, $70-77$.

KNoblock, K. (1966). Photosynthetische Sulfidoxidation grüner Pflanzen I. Planta 70, 73-86.

Krogmann, D. W. (1973). Photosynthetic reactions and components of thylakoids. In The Biology of Bluegreen Algae, pp. 80-98. Edited by N. G. Carr and B. A. Whitton. Oxford: Blackwell.

Lorenzen, H. \& Venkarataraman, G. S. (1969). Synchronous cell division in Anacystis nidulans. Archiv für Mikrobiologie 67, 25I-255.

SCholander, P. F. \& IVERSEN, O. (I958). New design of volumetric respirometers. Scandinavian Journal of Clinical Laboratory Investigation ro, 429-431.

SETLIKE, I. (I 957). Light dark transients in oxygen exchange of blue-green algae. Biochimica et biophysica acta 24, 436-437.

Sirenko, L. A., Stetsenko, N. M., Arendarchuk, V. V. \& Kuzimenko, M. K. (1968). Role of oxygen conditions in the vital activity of certain blue-green algae. Microbiology 37, 199-202. (Translation of Mikrobiologiya.)

STEWART, W. D. P. (1969). Biology and ecological aspects of nitrogen fixation by free-living micro-organisms. Proceedings of the Royal Society B r72, 367-388.

Stewart, W. D. P. \& Pearson, H. W. (1970). Effects of aerobic and anaerobic conditions on growth and metabolism of blue-green algae. Proceedings of the Royal Society B r75, 293-3I I.

Trebst, A. \& HARTH, E. (1970). On a new inhibitor of photosynthetic electron-transport in isolated chloroplasts. Zeitschrift für Naturforschung 25, I I $57-1$ I 59.

UTKILEN, H. C. (1973). Undersøkelse av vekst og sulfatopptak hos Anacystis nidulans. Thesis, Institute of General Microbiology, University of Bergen, Norway. 